\title{
A Case of Rosai-Dorfman Disease Presented with Neck Mass
}

\author{
Hee Soo Yoon, Dong Hwan Kim, Min Song Kim, and Yong Bae Ji $\mathbb{D}$ \\ Department of Otorhinolaryngology-Head and Neck Surgery, Hanyang University College of Medicine, Seoul, Korea
}

\author{
경부 종물을 주소로 내원한 Rosai-Dorfman Disease 1예 \\ 윤희수 · 김동환 · 김민송 · 지용배 \\ 한양대학교 의과대학 이비인후-두경부외과학교실
}

\author{
Received May 24, 2018 \\ Revised July 13, 2018 \\ Accepted July 23, 2018 \\ Address for correspondence \\ Yong Bae Ji, MD \\ Department of Otorhinolaryngology- \\ Head and Neck Surgery, \\ Hanyang University \\ College of Medicine, \\ 222 Wangsimni-ro, Seongdong-gu, \\ Seoul 04763, Korea \\ Tel $+82-2-2290-8580$ \\ Fax $+82-2-2290-3335$ \\ E-mail jyb20000@daum.net
}

Rosai-Dorfman disease, also known as the sinus histiocytosis with massive lymphadenopathy, is a rare and benign histioproliferative disease in which lymphadenopathy results from infiltration and dilatation of lymph node sinuses by large histiocytes. We experienced a case of a 59-year-old man, presenting bilateral cervical masses with pain since one month ago. Radiologically, there were multiple enlarged lymph nodes with homogenous contrast enhancement at both cervical areas. Excisional biopsy revealed that the tumor was consistent with the Rosai-Dorfman disease. The patient was treated successfully with corticosteroid. Herein, we report our experiences with literature reviews.

Korean J Otorhinolaryngol-Head Neck Surg 2019;62(6):351-4

Key Words Cervical lymph node · Histiocytosis · Lymphadenopathy ·

Rosai-dorfman disease.

\section{서 론}

Rosai-Dorfman 병은 1969년 Rosai와 Dorfman”이 림프절 증과 조직구증을 동반한 증례를 모아 sinus histiocytosis with massive lymphadenopathy로 처음으로 명명하였다.

증상은 임상적으로 무통성 림프절증과 발열, 중성구증가 증, erythrocyte sedimentation rate 증가와 다세포군 고감 마글로불린혈증(polyclonal hypergammaglubulinemia)을 특징으로 한다. 주로 경부 림프절을 침범하며 림프절 외 침범 (extranodal disease) 형태를 보이는 경우는 30 40\%로 피 부, 상기도, 부비동, 갑상선, 뇌 등 다른 장기의 침범도 보고 된다. 대개는 악화되었다가 소실되는 완만한 임상 경과를 보 이는 것으로 알려져 있으나 주요 장기의 광범위한 침범으로

This is an Open Access article distributed under the terms of the Creative Commons Attribution Non-Commercial License (https://creativecommons.org/licenses/by-nc/4.0) which permits unrestricted non-commercial use, distribution, and reproduction in any medium, provided the original work is properly cited.
사망에 이르기까지 하는 다양한 임상 양상을 보인다..$^{2-4)}$

대개는 소아나 젊은 성인에서 발생하는 것으로 보고되고 있으며, 남성이 여성보다 1.4 배 정도 많은 것으로 보고된다. 인 종적으로는 백인과 흑인에서 발병률의 차이는 없는 것으로 알려져 있으나 동양인에서는 매우 드문 것으로 알려져 있다.,5) 저자들은 최근 경부 종물을 주소로 내원한 환자에서 RosaiDorfman 병을 진단하고 치험 하였기에 문헌 고찰과 함께 보 고하는 바이다.

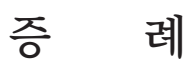

59세 남자 환자가 약 한달 전부터 발생한 우측 경부 종물 을 주소로 내원하였다. 종물은 약간의 통증을 동반하였으나 발열이나 인후통은 없었고 체중 감소나 야간 발한 등의 증상 도 관찰되지 않았다. 또한 과거력에서 특별한 기저질환이나 수술받은 병력은 없었다. 병변에 대해 환자는 별다른 조치 없 
이 경과 관찰하며 지내다가 수 일전부터 약간의 통증이 생겨 병원으로 내원하였다. 신체검사에서 경부 우측 level II에서 4 $\times 4 \mathrm{~cm}$ 정도 크기의 약간의 압통을 동반한 종물이 촉지 되 었으며, 혈액학적 검사에서는 특이 소견이 관찰되지 않았다. 영상의학 검사로 경부 전산화단층촬영을 시행하였으며, 우 측 경부 level I-V, 좌측 level II에 다수의 증가된 크기의 림 프절들이 관찰되었으며, 가장 큰 림프절은 우측 level II에서 약 $4 \times 3.5 \mathrm{~cm}$ 로 측정되었다. 림프절은 비교적 둥근 형태로, 내부는 균일하게 조영 증강되었으며, 조직으로의 침범은 관 찰되지 않고 경계는 분명하였다(Fig. 1).

이에 급성림프절염, 악성 림프종, Kimura 병, Castleman's 병 등을 감별해야 할 것으로 사료되어, 진단에 불충분할 수도 있는 세침흡인검사 대신 절제 생검을 시행하였다. 수술 소견 상 우측 경부 level II에서 다수의 크기가 증가된 림프절들이 관찰되었으며, 림프절들은 비교적 경계가 분명하여 주변과 박리가 용이하였다. 병리조직 검사에서는 전체적인 림프절의 구조는 유지되는 상태에서 확장된 굴(dilated sinus)이 세포질 이 창백한 조직구로 채워져 있는 소견을 보였으며, 면역조직 화학염색상 CD3, CD20, CD79a, CD21, CD68 염색에 양성 을 보였으며, S-100 염색에 강한 양성 소견을 보였고, CD1a 항 원에는 음성을 보여, Rosai-Dorfman 병에 합당한 것으로 판 단되었다(Fig. 2).

이에 prednisolone을 $1 \mathrm{mg} / \mathrm{kg}$ 로 2주간 사용 후 $0.5 \mathrm{mg} / \mathrm{kg}$ 으로 감량하여 치료를 시작하였으며 3개월간 치료 후 더 이 상 촉진되는 경부 종물은 관찰되지 않아 감량을 거쳐 중단 하였다. 하지만 술 후 10 개월째 경도의 통증 및 림프절의 종 창이 다시 발생하여 내원하였으며, 미열이 동반되었다. 추적 한 경부 전산화단층촬영상 양측 경부 림프절이 다시 종창된
소견을 보였다(Fig. 3). 이에 질환의 재활성으로 판단하고 다 시 prednisolone을 $1 \mathrm{mg} / \mathrm{kg}$ 으로 2주간 사용 후 $0.5 \mathrm{mg} / \mathrm{kg}$ 으로 4개월간 투여하였다. 이후 환자는 증상 소실되어 치료 를 중단하였고, 현재 술 후 21 개월째까지 관찰 중이다.

\section{고 찰}

Rosai-Dorfman 병은 매우 드문 질환으로 림프절 종창을 주소로 내원한 환자에서 초기에 의심하기는 매우 어렵다.

원인으로 Epstein-Barr 또는 Herpes와 같은 바이러스가 발 병에 관여한다는 가설이 있으나 Rosai-Dorfman 병의 발병 기전은 현재까지 명확히 밝혀지지 않았다. 다만 잠복 감염 또는 감염원에 대한 면역반응에 의해 조직구의 이상증식이 초래된다는 가설이 제기되고 있으며, 감염원으로 EpsteinBarr 또는 Herpes와 같은 바이러스가 제시되고 있지만 아직 증거는 부족하다. ${ }^{2)}$ 반응성 림프절의 단핵구에서 분비되는 macrophage-colony stimulating factor(M-CSF)가 단핵구 에 대해 화학주성(chemotaxis)을 초래하여 병변에서 RosaiDorfman 병의 조직구로 분화를 초래하는 것이 주된 기전으 로 보고된다. 단, $\mathrm{M}-\mathrm{CSF}$ 분비를 초래하는 기전은 아직 밝혀 지지 않았다. ${ }^{7)}$

대개는 점진적으로 발병하며, 활동성 단계를 지나 자연적으 로 소실되었다가 재발되기도 한다고 알려져 있다. 하지만 아 직까지 재발의 빈도나 재발과 관련된 인자에 대해서는 잘 알 려지지 않았다. 대개는 림프절을 침범하며 경부 림프절이 가장 흔히 침범되는 부위이며 다음으로 서혜부, 액와부, 종격동 림 프절 순으로 침범 된다. ${ }^{2)}$

본 증례에서도 경부 림프절을 침범하여 다발성 경부 림프절
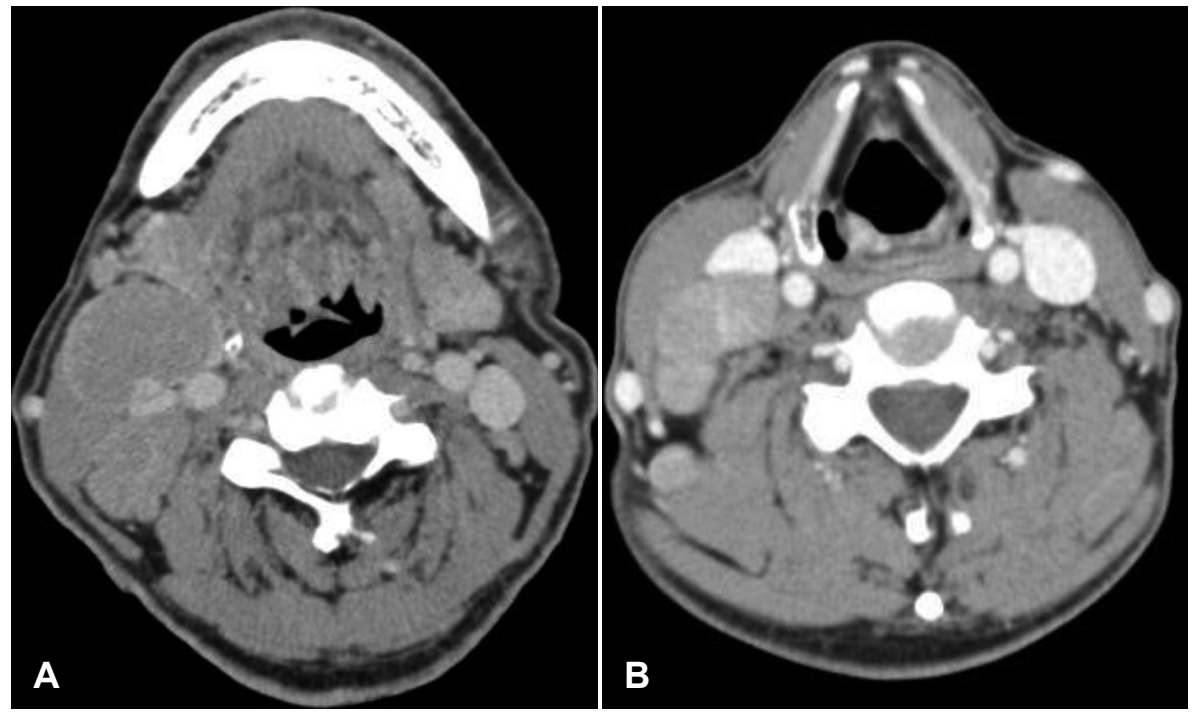

Fig. 1. Pretreatment radiologic findings. Neck CT scan showed multiple enlarged lymph nodes at right level II, III, IV, V, and left level II (A and $B$ ). The lymph nodes were conglomerated and homogenously enhanced. 

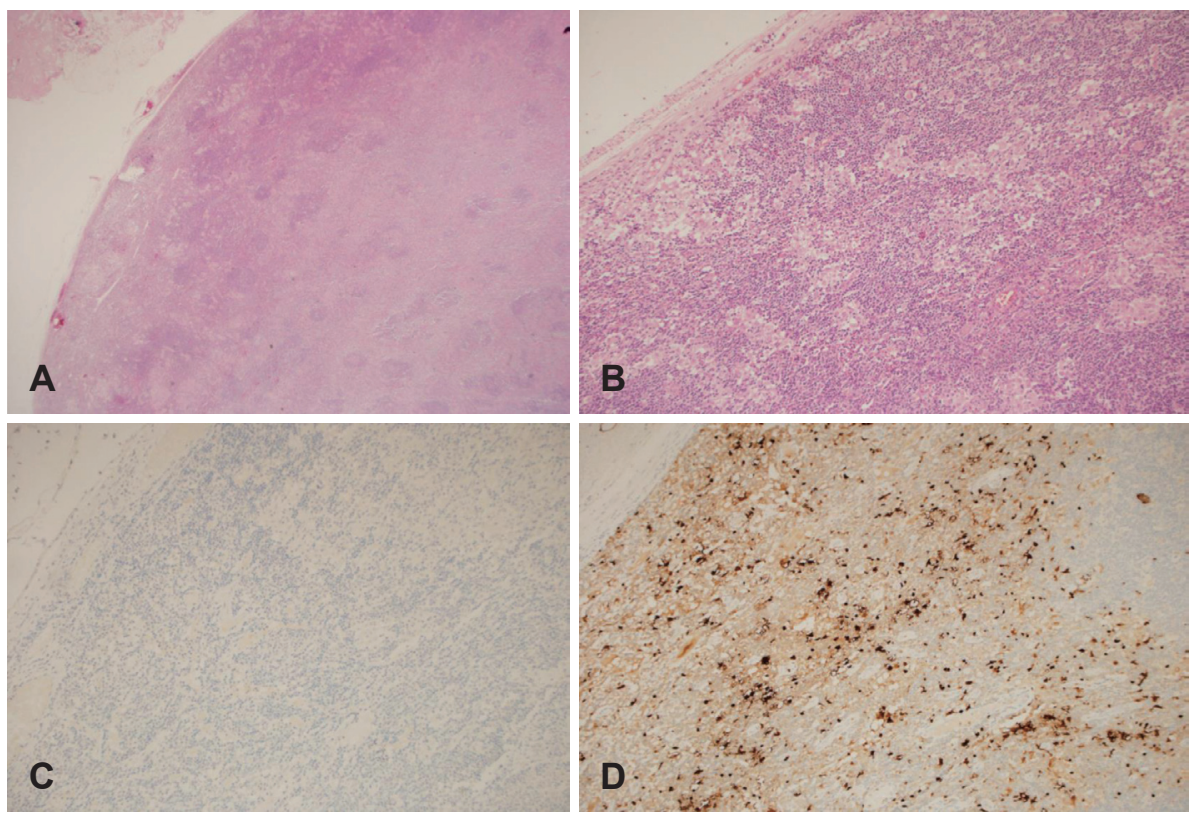

Fig. 2. Pathologic findings. The overall architecture of the lymph node is intact, and the sinuses are dilated with numerous histiocytes (H\&E, $\times 12.5)(A)$. Sinus are filled with histiocytes abundant pale cytoplasm $(H \& E \times 100)(B)$. Negative staining of Langerhans cells for CD1a (CD1a, × 100) (C). Increased number of histiocytes with positive staining of S-100 (S-100, × 100) (D).
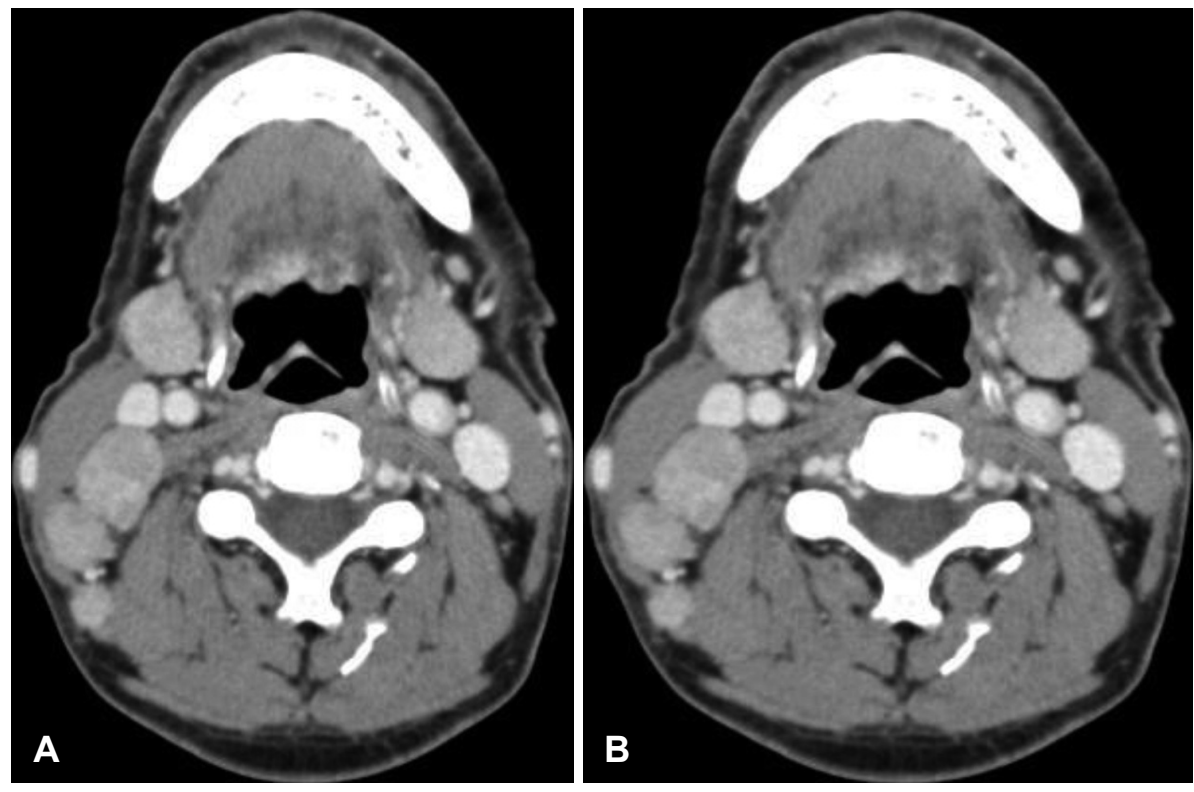

Fig. 3. Follow up radiologic findings. Follow up CT scan showed multiple enlarged lymph nodes at both neck level II, III, IV, and V (A and B).

의 증식으로 나타났다. 다발성 경부 림프절 종대를 보이는 경우에서 Rosai-Dorfman 병을 진단하기 위해서는 먼저 전이 성 경부 종물이 배제되어야 한다. 또한 그 외에도 호지킨 또는 비호지킨 림프종, 악성 조직구증, 단핵구성 백혈병 등과 같은 림프세망내피성 악성종양(lymphoreticular malignancy) 들과 코경화증(Rhinoscleroma), Wegener's 육아종증 등의 조직 구증 질환도 감별이 되어야 한다. ${ }^{5,8)}$

경부 림프절이 가장 흔히 침범되는 부위지만 림프절 외 침 범이 있을 경우는 더욱 감별하기 어렵다. 림프절 외 침범은 약 20 40\% 정도에서 발생하는 것으로 보고되고 있으며, 침범
된 부위에 따라 치명적인 결과를 초래하여 사망에 이르게 되 는 경우도 있으므로 진단할 때 주의 깊게 임상적 소견과 조 직학적 소견을 고려해야 한다. ${ }^{2,3}$

조직학적으로는 미만성 림프형질세포성 침윤(diffuse lymphoplasmatic infiltration), Russel 소체(Russel body), 거품형 조직구(foamy histiocytes), emperipolesis(세포질 내 림프구 포식 조직구, histiocytes with phagocytized lymphocytes within the cytoplasm)를 특징으로 하며, 면역조직화학염색 상 s-100, alpha-antichymotrypsin, CD68 염색에 양성을 보 이고, $\mathrm{CDla}$ 에는 음성을 보이는 특징을 보인다. 다른 림프구 
증식성 질환과의 감별을 위해 면역조직화학염색을 포함한 조직학적인 확인이 진단에 가장 중요한 역할을 한다. ${ }^{910)}$

본 증례에서도 위와 같은 특징과 함께 S-100에 양성 소견을 보이며, CDla에는 음성을 보이는 특징을 통해 진단할 수 있었 다. 림프절 외 침범에서는 전반적으로 림프절을 침범했을 때 보다 섬유화가 심하고, 정상 조직구의 숫자가 더 감소해 있으 며, 림프구 포식 조직구의 증식 정도가 심하지 않아서 진단을 위해 더 많은 양의 조직을 필요로 한다고 보고된다."

영상의학 소견으로 전산화단층촬영에서는 침범된 림프절이 균일하게 조영 증강되는 특성을 보이며, 자기공명영상에서는 강한 조영 증강과 함께 $\mathrm{T} 1, \mathrm{~T} 2$ 강조영상에서 모두 중등도 신 호 강도를 보인다고 알려져 있다. ${ }^{11}$

치료는 정립된 바 없지만 약 $50 \%$ 에서는 별다른 치료 없이 자연 소실된다고 보고되고 있다. ${ }^{9)}$ 따라서 증상이 없는 경우 는 치료 없이 관찰하기도 하지만 상기도를 압박하거나 주요 기관을 침범하는 증상이 발생할 경우에는 적극적인 치료가 필요하다. ${ }^{5,912,13)}$ 본 증례에서는 병변부위의 통증을 동반하였 기 때문에 치료가 필요하였으나, 림프절 외 침범을 의심할 만 한 소견은 관찰되지 않아 추가적인 검사는 시행하지 않았다. 수술은 조직학적인 진단을 위하거나 압박이나 폐쇄에 의한 증상을 해결하기 위해 사용할 수 있으며, 수술적 제거만으로 는 재발하는 경우가 많은 것으로 알려져 있다. 방사선치료도 시도된 바 있으나 그 효용성은 명확히 밝혀지지 않았으며, 스 테로이드가 크기를 줄이거나 발열을 해소하는 데 도움이 되 는 것으로 알려져 있다. ${ }^{12,13)}$ 본 증례도 스테로이드 치료 후 림 프절 크기가 감소하고 통증 및 발열이 소실되는 증상의 호전 을 확인할 수 있었고, 한 번의 재발에도 장기간 스테로이드 사용을 통하여 병변이 소실되는 것을 확인할 수 있었다.

결론적으로 Rosai-Dorfman 병은 특이한 병리적 소견을 동반하는 질환으로 주로 다양한 림프절을 침범하며 두경부 종물로 발생하는 경우도 있다. 따라서 두경부에 종물이 발견 되었을 때에 감별 진단으로 고려되어야 하며, 이를 위해 조직 학적 확인이 반드시 필요하다. 진단 후에는 림프절 외 침범에 유의하며 치료 및 추적 관찰 계획을 수립해야 할 것으로 사
료된다.

\section{ORCID}

Yong Bae Ji

\section{REFERENCES}

1) Rosai J, Dorfman RF. Sinus histiocytosis with massive lymphadenopathy. A newly recognized benign clinicopathological entitiy. Arch Pathol 1969;87(1):63-70.

2) Carbone A, Passannante A, Gloghini A, Devaney KO, Rinaldo A, Ferlito A. Review of sinus histiocytosis with massive lymphadenopathy (Rosai-Dorfman disease) of head and neck. Ann Otol Rhinol Laryngol 1999;108(11 Pt 1):1095-104.

3) Hashimoto K, Kariya S, Onoda T, Ooue T, Yamashita Y, Naka K, et al. Rosai-Dorfman disease with extranodal involvement. Laryngoscope 2014;124(3):701-4.

4) Yajima M, Nakajima K, Hirato J, Chikamatsu K. Extranodal soft tissue Rosai-Dorfman disease of the head and neck and its diagnostic difficulty. Auris Nasus Larynx 2016;43(3):345-9.

5) Pinto DC, Vidigal TA, Castro BD, Santos BH, Sousa NJ. Rosai-Dorfman disease in the differential diagnosis of cervical lymphadenopathy. Braz J Otorhinolaryngol 2008;74(4):632-5.

6) La Barge DV 3rd, Salzman KL, Harnsberger HR, Ginsberg LE, Hamilton BE, Wiggins RH 3rd, et al. Sinus histiocytosis with massive lymphadenopathy (Rosai-Dorfman disease): imaging manifestations in the head and neck. AJR Am J Roentgenol 2008;191(6):W299-306.

7) Middel P, Hemmerlein B, Fayyazi A, Kaboth U, Radzun HJ. Sinus histiocytosis with massive lymphadenopathy: evidence for its relationship to macrophages and for a cytokine-related disorder. Histopathology 1999;35(6):525-33.

8) Santra G, Das BK, Mandal B, Kundu SS, Bandopadhyay A. RosaiDorfman disease. Singapore Med J 2010;51(10):173-5.

9) Pulsoni A, Anghel G, Falcucci P, Matera R, Pescarmona E, Ribersani $\mathrm{M}$, et al. Treatment of sinus histiocytosis with massive lymphadenopathy (Rosai-Dorfman disease): report of a case and literature review. Am J Hematol 2002;69(1):67-71.

10) Fang $S$, Chen AJ. Facial cutaneous Rosai-Dorfman disease: a case report and literature review. Exp Ther Med 2015;9(4):1389-92.

11) Raslan OA, Schellingerhout D, Fuller GN, Ketonen LM. RosaiDorfman disease in neuroradiology: imaging findings in a series of 10 patients. AJR Am J Roentgenol 2011;196(2):W187-93.

12) Lai KL, Abdullah V, Ng KS, Fung NS, van Hasselt CA. RosaiDorfman disease: presentation, diagnosis, and treatment. Head Neck 2013;35(3):85-8.

13) Oka M, Kamo T, Goto N, Nagano T, Hirayama Y, Nibu K, et al. Successful treatment of Rosai-Dorfman disease with low-dose oral corticosteroid. J Dermatol 2009;36(4):237-40. 